\title{
Prion Protein and Metal Interaction: Physiological and Pathological Implications
}

\author{
Neena Singh*, Dola Das, Ajay Singh, \\ and Maradumane L. Mohan
}

The Department of Pathology, Case Western Reserve University, 2103, Cornell Road, Cleveland, Ohio 44106, USA

\begin{abstract}
Metal induced free radicals are important mediators of neurotoxicity in several neurodegenerative conditions such as Alzheimer's disease, Parkinson's disease, and Huntington's disease. Similar evidence is now emerging for prion diseases, a group of neurodegenerative disorders of humans and animals. The main pathogenic agent in all prion disorders is PrP-scrapie ( $\mathrm{PrP}^{\mathrm{Sc}}$ ), a $\beta$-sheet rich isoform of a normal cell surface glycoprotein known as the prion protein $\left(\mathrm{PrP}^{\mathrm{C}}\right)$. Deposits of $\mathrm{PrP}^{\mathrm{Sc}}$ in the brain parenchyma are believed to induce neurotoxicity through poorly understood mechanisms. Recent reports suggest that imbalance of brain metal homeostasis is a significant cause of $\mathrm{PrP}^{\mathrm{Sc}}$-associated neurotoxicity, though the underlying mechanisms are difficult to explain based on existing information. Proposed hypotheses include a functional role for $\mathrm{PrPC}^{\mathrm{C}}$ in metal metabolism, and loss of this function due to aggregation to the disease associated $\mathrm{PrP}^{\mathrm{Sc}}$ form as the cause of brain metal imbalance. Other views suggest gain of toxic function by $\mathrm{PrPSc}^{\mathrm{S}}$ due to sequestration of $\mathrm{PrP}^{\mathrm{C}}$-associated metals within the aggregates, resulting in the generation of redoxactive $\mathrm{PrP}^{\mathrm{Sc}}$ complexes. The physiological implications of some $\mathrm{PrP}^{\mathrm{C}}$-metal interactions are known, while others are still unclear. The pathological implications of $\mathrm{PrP}^{\mathrm{C}}$-metal interaction include metal-induced oxidative damage, and in some instances conversion of $\mathrm{PrP}^{\mathrm{C}}$ to a $\mathrm{PrP}^{\mathrm{Sc}}$-like form. Despite its significance, only limited information is available on PrP-metal interaction and its implications on prion disease pathogenesis. In this review, we summarize the
\end{abstract}

\author{
Abbreviations \\ $\mathrm{Fe}^{2+}:$ Ferrous iron \\ $\mathrm{Fe}^{3+}$ : Ferric iron \\ AD: Alzheimer's disease \\ CJD: Creutzfeldt-Jakob disease \\ HFE: hemochromatosis protein \\ HD: Huntington's disease \\ LIP: labile iron pool \\ N2a: mouse neuroblastoma cells \\ PD: Parkinson's disease \\ $\mathrm{PK}$ : proteinase-K \\ $\mathrm{PrP}^{-/-}$: mice lacking $\mathrm{PrP}$ expression \\ $\mathrm{PrP}^{\mathrm{C}}$ : prion protein \\ PrPSc: PrP-scrapie
}

ScN2a: scrapie infected mouse neuroblastoma cells

SOD: $\mathrm{Cu} / \mathrm{Zn}$ superoxide dismutase

Tf: transferrin, TfR: transferrin receptor

*neena.singh@case.edu physiological significance and pathological implications of PrP-metal interaction on prion disease pathogenesis.

\section{Introduction}

The current challenge facing prion research is the lack of an effective therapeutic strategy for prion disorders, a group of invariably fatal neurodegenerative conditions of humans and animals. Research in this area has been hampered due to incomplete understanding of the underlying mechanisms of neurotoxicity in these devastating diseases. The most favored hypothesis supported by numerous studies suggests that neurotoxicity in all prion disorders is mediated by PrP-scrapie ( $\mathrm{PrP}^{\mathrm{Sc}}$ ), a $\beta$-sheet rich conformation of a cell surface glycoprotein known as the prion protein $\left(\mathrm{PrP}^{\mathrm{C}}\right)$. The change in conformation of $\mathrm{PrP}^{\mathrm{C}}$ to $\mathrm{PrP}^{\mathrm{Sc}}$ confers certain biochemical and biophysical properties to $\mathrm{PrP}^{\mathrm{Sc}}$, which, unlike its counterpart $\mathrm{PrP}^{\mathrm{C}}$, becomes insoluble in non-ionic detergents and resists limited digestion by proteinase- $\mathrm{K}$ (PK). Deposits of PrPsc in the brain parenchyma are considered the principal cause of neurotoxicity, though the pathways involved in this process are poorly understood (Prusiner, 1998; Aguzzi and Polymenidou, 2004, Caughey and Baron, 2006). Intense research in this area has clarified several aspects of this process. It is now clear that PrPSc in the extracellular space does not induce toxicity in the absence of $\mathrm{PrPC}^{\mathrm{C}}$ expression on the neuronal plasma membrane, implicating $\mathrm{PrP}^{\mathrm{C}}$ in mediating the toxic signal (Malluci et al., 2003; Chesebro et al., 2005). On the other hand, accumulation of $\mathrm{PrP}^{\mathrm{Sc}}$ only on astrocytes induces neurotoxicity, suggesting indirect pathways of toxicity by $\mathrm{PrP}^{\mathrm{Sc}}$ (Jeffrey et al., 2004). Suggested pathways include secretion of toxic chemokines and factors by microglia in response to $\mathrm{PrP}^{\mathrm{Sc}}$, physical damage to the membrane structure by $\mathrm{PrP}^{\mathrm{Sc}}$ aggregates, interference with synaptic transmission, and toxicity through a labile by-product of the $\mathrm{PrP}^{\mathrm{C}}$ to $\mathrm{PrP}^{\mathrm{Sc}}$ conversion reaction (reviewed in Harris and True, 2006; Caughey and Baron, 2006). Evidence from cell model studies of familial prion disorders indicates abnormal processing and metabolism of mutant PrP as a possible cause of cytotoxicity, though the mechanism varies with specific mutations (Jin et al., 2000; Mishra et al., 2002; Gu et al., 2003). Other mechanisms such as activation of cell death pathways due to intracellular accumulation of $\mathrm{PrPSc}$ (Yadavalli et al., 2004; Kristiansen et al., 2005), crosslinking of neuronal $\mathrm{PrPC}^{\mathrm{C}}$ on the plasma membrane by PrPSc (Solforosi et al., 2004), and toxicity due to C-transmembrane and cytosolic forms of $\mathrm{PrP}^{\mathrm{C}}$ through unspecified pathways have also been suggested, but the details of underlying mechanisms remain unclear (Hegde et al., 1998; 1999; Ma et al., 2002; Ma and Lindquist, 2002; Heller et al., 2003; Wang et al., 2006).

An overlooked but equally important cause of neurotoxicity is the loss of normal function of $\operatorname{PrP}^{\mathrm{C}}$ due to conversion to the $\mathrm{PrP}^{\mathrm{Sc}}$ form. Information on this subject is limited since the normal function of $\mathrm{PrP}^{\mathrm{C}}$ remains ambiguous despite its ubiquitous presence and conservation through 
evolution. Transgenic mice lacking $\mathrm{PrP}^{\mathrm{C}}$ expression $\left(\mathrm{PrP}^{-/-}\right)$ do not develop a specific phenotype unless a prion-like protein Doppel is up regulated, making it difficult to ascertain the functional role of $\operatorname{PrPC}^{C}$ (Bueler et al., 1992). Other experimental models suggest several unrelated functions, including a role in signal transduction, cell adhesion, copper uptake and transport, as an anti-oxidant and anti-apoptotic protein, and others (Bounhar et al., 2001; Roucou et al., 2004; 2005; Roucou and LeBlanc, 2005; Harris and True, 2006). The diverse functions attributed to $\operatorname{PrP}^{C}$ probably reflect its involvement in an essential biochemical pathway that affects several cellular processes. Loss of this activity by the change in conformation of $\mathrm{PrP}^{\mathrm{C}}$ to $\mathrm{PrP}^{\mathrm{Sc}}$ is likely to induce toxicity due to loss of an essential function, together with gain of certain toxic properties by $\mathrm{PrPSc}^{\mathrm{Sc}}$.

One such pathway may involve the functional role of $\mathrm{PrP}^{\mathrm{C}}$ in copper and iron metabolism. Since these metals are redox-active, abnormal metabolism of either of these metals is likely to induce neurotoxicity due to the generation of free radicals. Such a mechanism has been observed in neurodegenerative conditions associated with protein aggregation such as Alzheimer's disease (AD) and Parkinson's disease (PD) (Moos and Morgan, 2004; Gerlach et al., 1994; Hayashi et al., 2006; Gaasch et al., 2007; Smith et al., 1997; 2007; Barnham and Bush, 2008). Recent reports indicate the presence of a similar phenomenon in prion disorders (Petersen et al., 2005; Singh et al., 2009a). Markers of oxidative stress and imbalance of metal homeostasis have been reported in prion disease affected brains, lending support to this assumption (Kim et al., 2000;
Rossi et al 2004; Petersen et al., 2005; Pamplona et al., 2008; Singh et al., 2009a). In this review, we summarize evidence related to the interaction of $\mathrm{PrPC}^{\mathrm{C}}$ with various metals, followed by the physiological and pathological implications of PrP-metal interaction. In particular, the role of $\mathrm{PrP}^{\mathrm{C}}$ in copper and iron metabolism is reviewed since these metals are essential for several metabolic processes, and are also toxic if mismanaged due to their redox-active nature.

\section{PrP-metal interactions}

Several studies have reported the interaction of $\operatorname{PrPC}$ with metals using in vitro and in vivo models. The in vitro studies have been more revealing due to the simplicity and accuracy of the readout compared to cell and animal models where metal metabolism is complex and the interaction of individual proteins with metals is often missed due to low affinity or their transient nature. Observations from in vitro studies using re-folded, full-length recombinant PrP or its fragments have lead to important findings regarding PrP-metal interaction and its significance to prion disease pathogenesis. It is now clear that recombinant PrP binds several divalent cations, including copper, iron, zinc, manganese and nickel (Pan et al., 1992; Hornshaw et al., 1995a; 1995b; Brown et al., 2000; Jackson et al., 2001; Jones et al., 2004; 2005; Basu et al., 2007). The highly conserved octa-peptide repeat region of $\mathrm{PrP}$ is the principal metal binding site, and its affinity for metals is highest for copper, followed by nickel, zinc, and manganese (Jackson et al. 2001). A diagrammatic representation of the interaction of $\mathrm{PrP}^{\mathrm{C}}$ with copper and

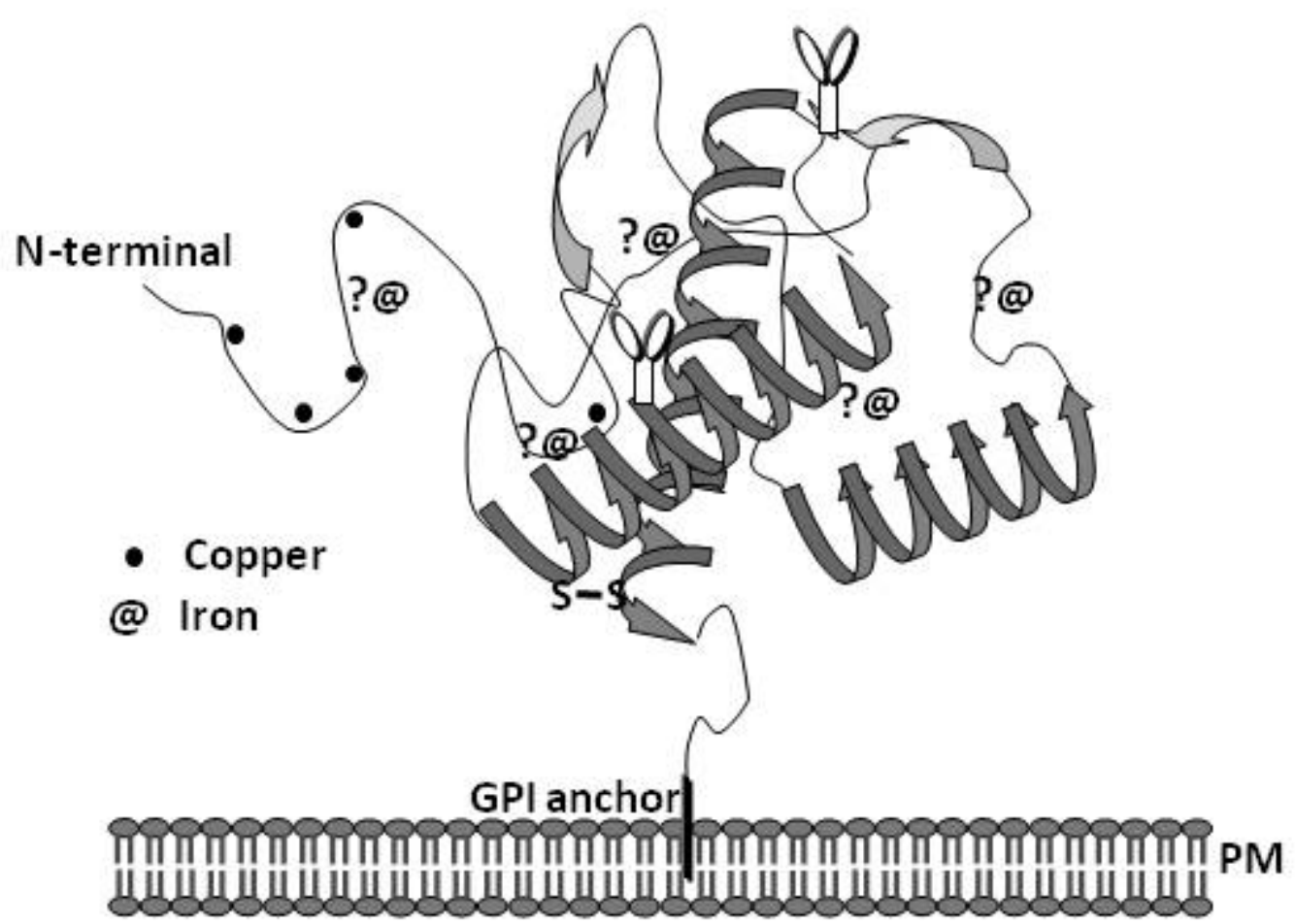

Figure 1. A model of $\mathrm{PrP}^{\mathrm{C}}$ demonstrating the known copper binding sites in the octa-peptide region and histidine residues 96 and 111. The association of $\operatorname{PrPC}^{\mathrm{C}}$ with iron is based on unpublished data from recombinant full length $\mathrm{PrPC}$ and its fragments. 
iron is shown in Figure 1. The interaction of $\mathrm{PrP}^{\mathrm{C}}$ with metals is important to understand because of the physiological and pathological implications of this association. For example, $\mathrm{PrP}^{\mathrm{C}}$ is believed to mediate the uptake of copper and iron, suggesting a role in cellular copper and iron metabolism (Brown and Harris, 2003; Singh et al., 2009b,c). On the other hand, interaction of recombinant and cell associated PrPC with certain metals induces a change in its conformation to the disease associated PrPSc form, suggesting their role in prion disease pathogenesis (Deleaut et al., 2007; Basu et al., 2007). The conversion of $\mathrm{PrP}^{\mathrm{C}}$ to the $\mathrm{PrP}^{\mathrm{Sc}}$ form increases its affinity for nickel while decreasing the binding of zinc and manganese, indicating specific interaction of different metals with the normal and the disease associated $\mathrm{PrP}^{\mathrm{Sc}}$ form (Jackson et al., 2001).

The association of $\mathrm{PrPC}^{\mathrm{C}}$ with copper is better characterized than its interaction with other metals. Four copper binding sites have been identified within the octapeptide repeat region of $\mathrm{PrP}^{\mathrm{C}}$ with additional sites on histidine residues 96 and 111 (Burns et al., 2003). Purified $\mathrm{PrP}^{\mathrm{C}}$ from mouse and human brains also binds copper, substantiating the in vitro observations (Brown et al., 2001; Wong et al., $2001 b)$. The affinity of $\mathrm{PrP}^{\mathrm{C}}$ for copper is higher compared to zinc, and even a large excess of zinc cannot displace copper from the octa-peptide repeat region of full-length $\mathrm{PrP}^{\mathrm{C}}$ under in vitro conditions (Jackson et al., 2001; Walter et al., 2007). However, physiologically relevant levels of zinc in cell models alter the distribution of $\mathrm{PrP}^{\mathrm{C}}$ bound copper with relative ease, indicating the influence of other catalytic factors in determining the metal ion occupancy of $\mathrm{PrPC}^{\mathrm{C}}$ (Watt and Hooper, 2003). These observations suggest that the interaction of $\mathrm{PrP}^{\mathrm{C}}$ with zinc may be more significant given the relative abundance of this metal in the brain (Qin et al., 2002; Watt and Hooper, 2003; Walter at al., 2007; Kenward et al., 2007). $\operatorname{PrP}^{\mathrm{C}}$ also binds manganese, probably in the C-terminal region between residues 91-230 or overlapping with the copper binding site at His-96 (Treiber et al., 2007; Brazier et al., 2008). Although these observations are useful, the data need to be interpreted with caution since in vitro reactions do not always represent the complex milieu of $\mathrm{PrP}^{\mathrm{C}}$ in cells or in the brain.

The interaction of $\mathrm{PrP}^{\mathrm{C}}$ with some of these metals alters its structure such that it simulates $\mathrm{PrPSc}^{\mathrm{S}}$ in certain biochemical properties including detergent insolubility and resistance to limited digestion by proteinase-K. Other metals induce this change in $\mathrm{PrP}^{\mathrm{C}}$ by their absence such as in the presence of a specific chelator, suggesting that modification of metal ion occupancy of $\mathrm{PrP}^{\mathrm{C}}$ is equally significant in bringing about this change (Deleaut et al., 2007). Thus, addition of manganese promotes a change in the conformation of recombinant $\mathrm{PrP}^{\mathrm{C}}$ to $\mathrm{PrP}^{\mathrm{Sc}}$, while zinc is believed to inhibit fibril formation and promote inter-molecular reactions (Brown et al., 2000; Giese et al., 2004; Tsenkova et al., 2004; Bocharova et al., 2005; Kim et al., 2005; Abdelraheim et al, 2006; Treiber et al., 2006; Kenward et al., 2007). Addition of zinc and copper to the toxic peptide of PrP, a model often used for studying prion-mediated toxicity, increases its aggregation and toxicity to cells (Jobling et al., 1999; 2001). A similar change in the conformation of $\mathrm{PrPC}^{\mathrm{C}}$ to a $\mathrm{PrPS}^{\mathrm{S}}$-like form is noted when PrP-expressing yeast cells are grown in medium supplemented with copper or manganese (Treiber et al., 2006). This reaction is reversed by adding specific chelators such as bathocuproinedisulfonic acid and clioquinol to the medium, reinforcing the idea that only specific metals induce this reaction. Despite this information and additional data emphasizing the significance of $\mathrm{PrP}^{\mathrm{C}}$ and $\mathrm{PrP}^{\mathrm{Sc}_{-}}$-metal interaction, neither the physiological nor the pathological significance of this interaction is clearly understood.

\section{Physiological significance of PrP-metal interaction}

Observations from neuroblastoma cells suggest that $\mathrm{PrPC}$ binds extracellular copper ions and delivers to endocytic compartments, functioning as a copper uptake protein (Pauly and Harris, 1998; Brown and Harris, 2003). The octa-peptide repeats of $\mathrm{PrP}^{\mathrm{C}}$ are essential for this process since deletion of this region inhibits copper uptake (Perera and Hooper, 2001). The octa-peptide repeat region is also believed to function as a reductase, reducing $\mathrm{Cu}$ (II) ions before transport across the endosomal membrane to the cytosol (Miura et al., 2005). Although these observations suggest that $\mathrm{PrP}^{\mathrm{C}}$ may be a major copper delivery protein, surprisingly, there is minimal difference in the copper content of brains from wild type and transgenic mice lacking PrP expression $\left(\mathrm{PrP}^{-/}\right.$) (Giese et al., 2005). However, contradictory studies claim a significant difference in copper levels between wild type, $\mathrm{PrP}^{-/-}$, and scrapie infected mouse brains, suggesting a prominent role for $\mathrm{PrPC}^{\mathrm{C}}$ in maintaining copper homeostasis in the brain (Brown et al., 1997, 1998; Wong et al., 2001c; Thackray et al., 2002). Likewise, conflicting results regarding brain copper levels have been reported in $\mathrm{PrP}^{\mathrm{C}}$ over-expressing mice (Herms et al., 1999; Kretzschmar et al., 2000; Waggoner et al., 2000; Stuermer and Plattner, 2005), leaving the matter unsettled.

The interaction of $\mathrm{PrPC}^{\mathrm{C}}$ with iron is a relatively recent finding, and the physiological significance of this association is becoming increasingly clear from studies indicating a functional role for $\mathrm{PrP}^{\mathrm{C}}$ in cellular iron uptake and transport (Basu et al., 2007; Singh et al., 2009b; 2009c). Unlike most other divalent cations, iron is an essential component of enzymes and proteins and is required for optimal neuronal growth and function (Beard and Connor, 2003). On the other hand, iron is also considered a toxin due to its ability to exist in two oxidation states (ferric $\mathrm{Fe}^{3+}$ and ferrous $\mathrm{Fe}^{2+}$ ) (Thompson et al., 2001; Kaplan, 2002). Due to this reason, iron transport into and out of the cells is tightly regulated. It is surprising that $\mathrm{PrPC}^{\mathrm{C}}$ influences the cellular iron pool within this tightly regulated mechanism of iron uptake, transport, and utilization (Singh et al., 2009b; 2009c). These observations have significant bearing on the pathogenesis of prion disorders since aggregation of $\mathrm{PrP}^{\mathrm{C}}$ is likely to disturb cellular iron homeostasis, resulting in neurotoxicity.

$\mathrm{PrPC}^{\mathrm{C}}$ has been demonstrated to influence iron metabolism in cells expressing normal and mutant PrP forms and in $\mathrm{PrP}^{-/-}$transgenic mouse models (Singh et al., 2009b, 2009c). Over-expression of $\mathrm{PrPC}^{\mathrm{C}}$ in cultured neuroblastoma cells increases the cellular labile iron pool (LIP) and iron saturation of ferritin, suggesting a role for $\mathrm{PrPC}$ in iron uptake. It is interesting to note that cells expressing pathogenic and non-pathogenic mutations of PrP alter the cellular LIP and iron saturation of ferritin differentially. This difference in the cellular iron content is maintained even when cells are cultured in the presence of excess extracellular iron, indicating a dominant role in iron uptake (Singh et al., 2009b). Furthermore, stimulation of endocytosis by a PrP-specific antibody increases intracellular iron stores, suggesting that $\mathrm{PrP}^{\mathrm{C}}$ mediates uptake of iron from the extra- 
cellular milieu. Unlike ceruloplasmin, $\operatorname{PrP}^{\mathrm{C}}$ does not mediate the efflux of excess iron from cells, confirming its role as an iron uptake protein (Jeong and David, 2003; Singh et al., 2009b). Presently it is unclear whether $\mathrm{PrPC}^{\mathrm{C}}$ mediates iron uptake using a novel pathway or by interacting with the conventional pathway of iron uptake and transport. It has been hypothesized that $\mathrm{PrP}^{\mathrm{C}}$ may influence iron uptake by interacting with the transferrin/transferrin receptor pathway as described for HFE (Waheed et al., 2002), or function as a ferric reductase to facilitate the transport of ferric iron from endosomes to cytosolic ferritin (Singh et al., 2009b).

Similar observations suggesting a positive effect of $\mathrm{PrP}^{\mathrm{C}}$ on systemic iron levels are noted when wild type mice are compared with $\mathrm{PrP}^{-/-}$mouse models. Deletion of $\mathrm{PrP}^{\mathrm{C}}$ in $\mathrm{PrP}^{-/-}$mice induces iron deficiency in the latter by decreasing the efficiency of iron transport from the intestinal lumen to the blood stream, and uptake of iron from the blood by parenchymal cells and cells of the hematopoietic lineage. Re-expression of $\mathrm{PrP}^{\mathrm{C}}$ corrects the iron deficiency in these mice, confirming the functional role for PrP in iron uptake (Singh et al., 2009c). Considering that $\mathrm{PrP}^{-/-}$mice are only mildly iron deficient, it is likely that $\mathrm{PrPC}^{\mathrm{C}}$ modulates the function of other iron uptake proteins or is involved in a pathway that compensates for its absence.

An important question that remains unanswered is the binding site and the affinity of $\mathrm{PrP}^{\mathrm{C}}$ for iron. In vitro experiments using recombinant $\mathrm{PrP}^{\mathrm{C}}$ and its fragments indicate that the octapeptide repeat region of $\mathrm{PrP}^{\mathrm{C}}$ is not essential for iron binding, and the iron and copper binding regions of $\mathrm{PrP}^{\mathrm{C}}$ do not overlap (unpublished observations). Limited data using different denaturing conditions suggest that the interaction of $\mathrm{PrPC}^{\mathrm{C}}$ with iron depends on the conformation of $\mathrm{PrP}^{\mathrm{C}}$ rather than a specific amino acid sequence. These studies are limited to recombinant $\operatorname{PrPC}$ since it is difficult to identify iron associated cellular $\operatorname{PrP}^{\mathrm{C}}$, suggesting that either the interaction of $\mathrm{PrP}^{\mathrm{C}}$ with iron is transient, or the affinity of $\mathrm{PrP}^{\mathrm{C}}$ for iron is not high enough for easy identification. A diagrammatic representation of possible mechanisms of iron uptake by $\mathrm{PrP}^{\mathrm{C}}$ is depicted in Figure 2. It is likely that after binding iron, $\operatorname{PrP}^{\mathrm{C}}$ moves from lipid rich domains in the plasma membrane to the vicinity of $\mathrm{TfR}$, where it might influence the binding of Tf to the TfR, internalization of $\mathrm{PrPC} / \mathrm{TfR} / \mathrm{Tf}$ complex, or endocytosis of $\mathrm{Tf} /$ $\mathrm{TfR}$ complex. It is also possible that $\mathrm{PrP}^{\mathrm{C}}$ influences iron

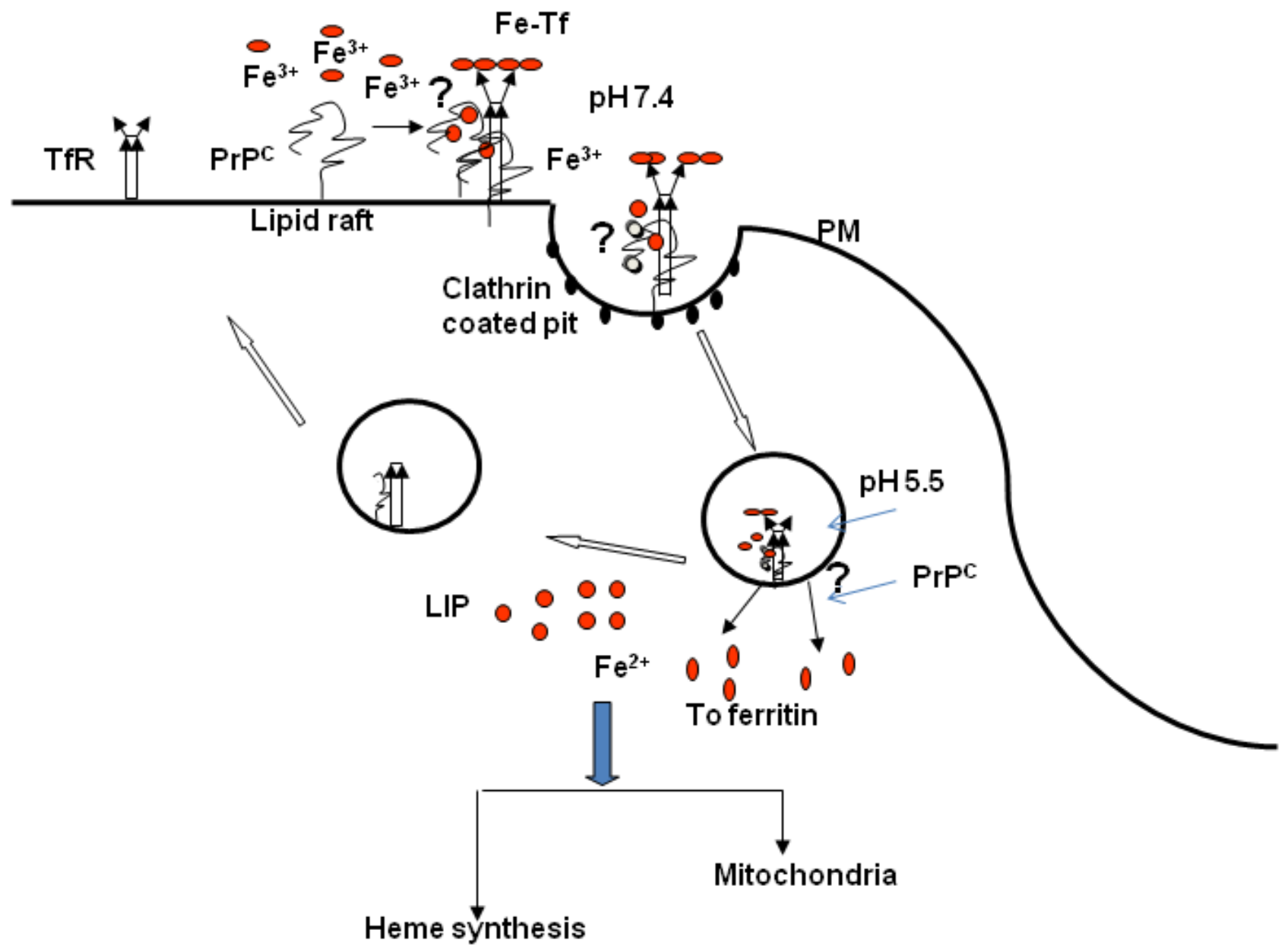

Figure 2. A representation of possible mechanisms by which $\mathrm{PrPC}^{\mathrm{C}}$ is likely to mediate cellular iron uptake. At the plasma membrane, $\mathrm{PrP}^{\mathrm{C}}$ may bind iron directly for transport to the cytosol through endocytosis. It is also likely that $\mathrm{PrPC}$ influences iron uptake indirectly by modulating the endocytosis association or endocytosis of the Tf/TfR complex. Alternately, PrPC may facilitate the transport of iron from the endosomal compartment to the cytosol by functioning as a ferric-reductase. In the cytosol, iron is used for metabolic processes, or stored in ferritin in a relatively inert form. 


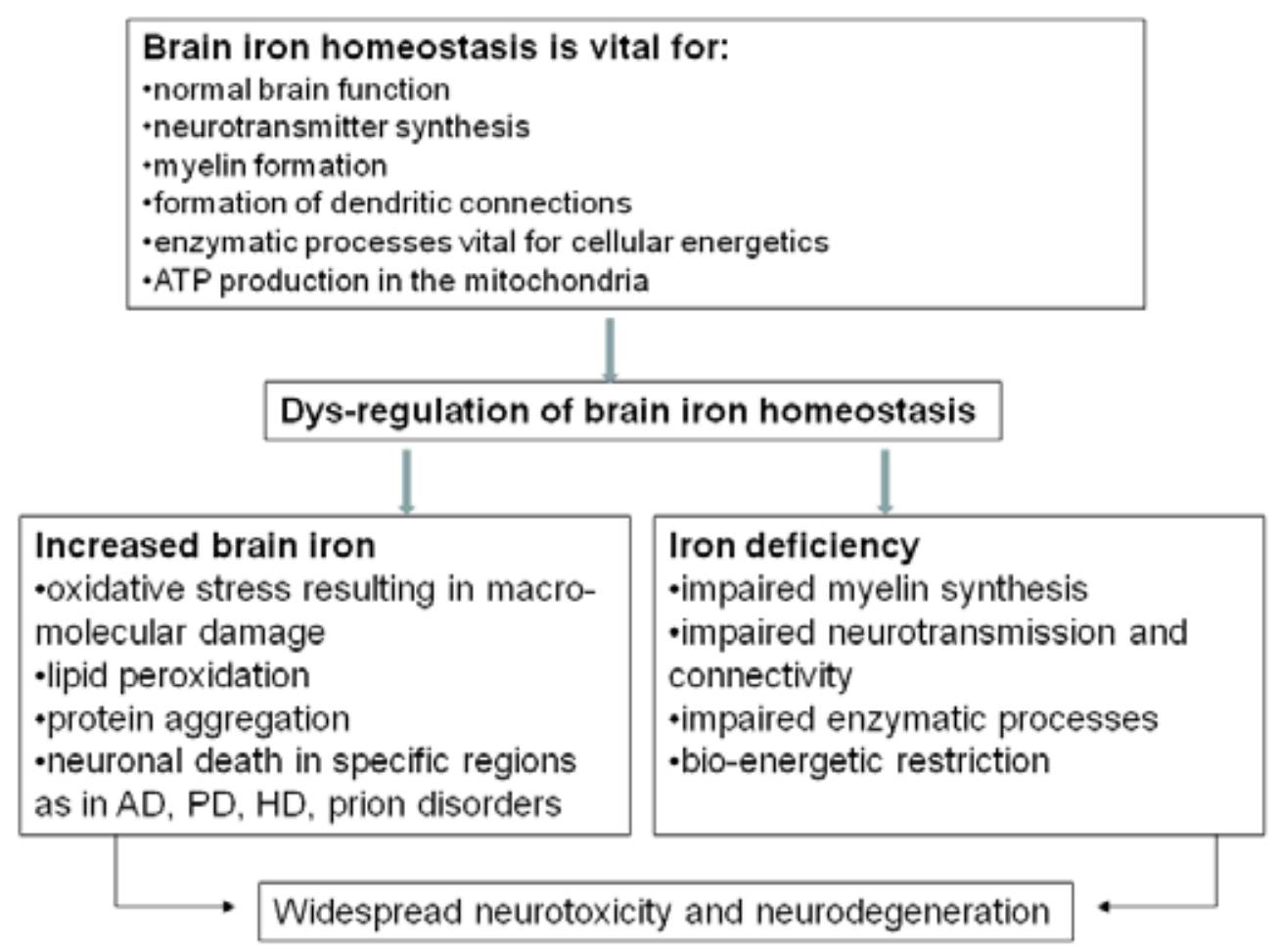

Figure 3. A model demonstrating the vital role of iron in brain function such as neurotransmitter synthesis, myelin formation, maintenance of dendritic connections, and other metabolic processes. Dys-regulation of brain iron homeostasis can induce neurotoxicity both by iron excess, and by iron deficiency. The former is a consequence of the redox-active nature of iron leading to oxidative stress, and the latter due to impairment of essential metabolic processes.

transport from the endosomes to the cytosol by functioning as a ferric-reductase as demonstrated for copper (Miura et al., 2005).

\section{Pathological implications of PrP-metal interaction}

Copper and iron have significant pathological implications due to their redox-active nature. For example, both copper and iron induce the conversion of $\mathrm{PrP}^{\mathrm{C}}$ to the $\mathrm{PrP}^{\mathrm{Sc}}$ form (Kim et al., 2005). Addition of copper increases the protease resistance and infectivity of denatured $\mathrm{PrPSc}$ in vitro, while copper chelation in vivo delays the onset of disease in prion infected mice (Pauly and Harris, 1998; Quaglio et al., 2001; Sigurdsson et al., 2003; Kuczius et al., 2004). Paradoxically, copper treatment inhibits $\mathrm{PrP}^{\mathrm{Sc}}$ formation in cells infected with mouse prions and delays the onset of disease in scrapie infected hamsters, demonstrating a protective role, perhaps by augmenting the function of $\mathrm{PrPC}^{\mathrm{C}}$ as a $\mathrm{Cu} / \mathrm{Zn}$ superoxide dismutase (SOD) (Vassallo and Herms, 2003; Hijazi et al., 2003; Kiachopoulos et al., 2004; Orem et al., 2006). These conflicting observations can perhaps be explained from in vitro studies where copper inhibits the amplification of PrPSc from purified brain-derived $\mathrm{PrP}^{\mathrm{C}}$ and recombinant $\mathrm{PrP}^{\mathrm{C}}$ by stabilizing its $\alpha$-helical structure, while it enhances the $\beta$-sheet structure of preformed PrP fibrils, thereby increasing their PrPSc content (Liu et al., 2007). Copper could therefore delay or augment disease progression based on the time when it is introduced to the animal.

An important consideration in evaluating the pathogenic consequences of $\mathrm{PrP}^{\mathrm{C}}$-metal interaction is the cellular compartment in which metal bound $\mathrm{PrP}^{\mathrm{C}}$ is exposed to free radicals. It has been observed that exposure of $\mathrm{PrPC}^{\mathrm{C}}$ expressing cells to a source of redox-active metal such as ferrous chloride induces the generation of PrPSc-like aggregates on the plasma membrane that accumulate within lysosomes in association with ferritin (Basu et al., 2007). These aggregates are also redox-active and initiate the generation of additional PrP-ferritin aggregates, propagating the $\mathrm{PrP}^{\mathrm{Sc}}$-like conformation within cells (Basu et al., 2007). Likewise, exposure of $\mathrm{PrP}^{\mathrm{C}}$ expressing cells to hemin, an iron containing compound, also results in the aggregation and degradation of $\operatorname{PrPC}^{\mathrm{C}}$ (Lee et al., 2007), implicating redox-iron in the generation and propagation of $\mathrm{PrPSc}$. Similar aggregation of $\alpha$-synuclein is noted in response to iron and copper (Paik et al., 2000; OstrerovaGolts et al., 2000; Golts et al., 2002; Takahashi et al., 2007), suggesting that protein aggregation by redox-active metals is not specific to $\operatorname{PrP}^{\mathrm{C}}$. However, the generation of additional $\mathrm{PrP}^{\mathrm{Sc}}$ aggregates by redox-active $\mathrm{PrP}^{\mathrm{Sc}}$ appears to be unique to PrP, explaining in part the propagation of $\mathrm{PrPS}^{\mathrm{Sc}}$ once initiated. Surprisingly, chelation of iron from diseased brain homogenates decreases the total amount of PK-resistant $\mathrm{PrPSc}^{\mathrm{Sc}}$, suggesting that iron is also involved

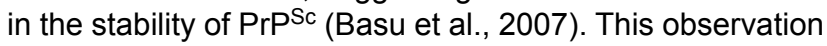
is of immense prophylactic value since iron chelation can be used as a means to decrease the infectivity of prion contaminated material.

Observations from mouse models of prion disease demonstrate an increase in the levels of iron regulatory proteins 1 and 2 and iron storage protein ferritin in the hippocampus and cerebral cortex of diseased brains, 
indicating the presence of brain iron imbalance (Kim et al., 2007). A similar imbalance of cellular iron homeostasis is observed in scrapie infected mouse neuroblastoma cells (ScN2a) that also show increased susceptibility to iron induced oxidative stress (Fernaeus et al., 2005; Fernaeus and Land, 2005). Imbalance of iron homeostasis is also observed in prion disease affected human, mouse, and hamster brains that demonstrate a phenotype of iron deficiency in the presence of increased total and redoxactive $\mathrm{Fe}^{2+}$ iron (Singh et al., 2009a). The iron deficiency in scrapie infected hamster brains is noted $\sim 6$ weeks after inoculation of the infectious material and correlates with $\mathrm{PrP}^{\mathrm{Sc}}$ levels, perhaps due to sequestration of iron in $\mathrm{PrPSc}_{-}$ ferritin complexes (Singh et al., 2009a). The redox-active

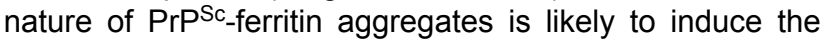
aggregation of additional $\mathrm{PrPC}^{\mathrm{C}}$, creating an ongoing state of iron imbalance and associated neurotoxicity in the diseased brain (Mishra et al., 2004; Basu et al., 2007). The associated

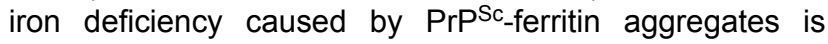
equally harmful especially since iron is required for several vital metabolic processes (Figure 3).

In addition to copper and iron, alteration in the homeostasis of manganese has also been reported in prion disease affected human and animal brains. In scrapie infected mice, levels of manganese are elevated in the peripheral blood, while in diseased cattle and sheep increased levels are noted in both the blood and brain tissue (Wong et al., 2001a, 2001b; Thackray et al., 2002; Hesketh et al. 2007; 2008). Surprisingly, altered levels of manganese have also been reported in scrapie resistant sheep that do not develop clinical disease, making it unlikely that the change is due to the disease process per se. However, limited studies make it difficult to explain the generality or the underlying cause of this abnormality. Other diseases that show elevated levels of manganese include hemochromatosis and diseases of the blood-brain barrier, information that may help in understanding the basis of manganese imbalance in prion disorders. Other reports indicate a decrease in the levels of copper and zinc in the brains of scrapie infected mice, although blood levels of zinc increase during disease progression as noted for manganese (Wong et al. 2001a, 2001b; Thackray et al., 2002). In human brains affected with $\mathrm{SCJD}, \mathrm{PrP}^{\mathrm{C}}$-associated copper is replaced by zinc, resulting in the loss of SOD-like activity of $\mathrm{PrP}^{\mathrm{C}}$, a possible cause of increased neurotoxicity due to oxidative stress. Further studies are necessary to understand this phenomenon fully.

\section{Summary and Perspective}

Despite overwhelming evidence implicating $\mathrm{PrPSc}$ in the pathogenesis of prion disorders, the mechanistic details underlying the neurotoxicity associated with these disorders remain unclear. The association of $\mathrm{PrP}^{\mathrm{C}}$ with redox-active metals such as copper and iron provides new insight into the role of metal-induced oxidative stress in these disorders. Observations from cell and mouse models suggest that $\mathrm{PrPC}^{\mathrm{C}}$ is involved in copper and iron uptake. Although $\mathrm{PrPC}^{\mathrm{C}}$ is not a major iron or copper modulating protein, compromised levels of these metals due to aggregation of $\mathrm{PrP}^{\mathrm{C}}$ to the $\mathrm{PrP}^{\mathrm{Sc}}$ form are likely to affect cell health due to their redox-active nature. At the same time, PrPSc assumes a redox-active nature due to sequestration of iron

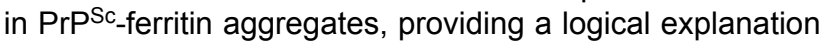

for imbalance of iron homeostasis in prion disease affected brains. This phenotype is likely to induce oxidative stress and neuronal damage, and could contribute significantly to prion disease associated neurotoxicity. Although the role of redox-active metals in prion disease pathogenesis is still at its formative stage, sufficient information exists to promt future investigations on this subject that may lead to the development of anti-oxidants and metal chelators as useful therapeutic agents.

\section{References}

Aguzzi, A., and Polymenidou, M. (2004). Mammalian prion biology: one century of evolving concepts. Cell. 116, 313-327.

Abdelraheim, S.R., Královicová, S., and Brown, D.R. (2006). Hydrogen peroxide cleavage of the prion protein generates a fragment able to initiate polymerisation of full length prion protein. Int J Biochem Cell Biol. 38,1429-1440.

Barnham, K.J., and Bush, A.I. (2008). Metals in Alzheimer's and Parkinson's diseases. Curr. Opin. Chem. Biol. 12, 222-228.

Basu, S., Mohan, M.L., Luo, X., Kundu, B., Kong, Q., and Singh, N. (2007). Modulation of PK-resistant PrPSc in cells and infectious brain homogenate by redoxiron: Implications for prion replication and disease pathogenesis. Mol. Biol. Cell. 18, 3302-3312.

Beard, J.L., and Connor, J.R. (2003). Iron status and neural functioning. Ann. Rev. Nutr. 23, 41-58.

Bocharova, O.V., Breydo, L., Salnikov, V.V., and Baskakov, I.V. (2005) Copper(II) inhibits in vitro conversion of prion protein into amyloid fibrils. Biochem. 44, 6776-6787.

Bounhar, Y., Zhang, Y., Goodyer, C.G,, and LeBlanc, A. (2001). Prion protein protects human neurons against Baxmediated apoptosis. J. Biol. Chem. 276, 39145-39149.

Brazier, M.W., Davies, P., Player, E., Marken, F., Viles, J.H., and Brown, D.R. (2008). Manganese binding to the prion protein. J. Biol. Chem. 283, 12831-12839.

Brown, D.R, Qin, K., Herms, J.W., Madlung, A., Manson, J., Strome, R., Fraser, P.E., Kruck, T., Von Bohlen, A., SchulzSchaeffer, W., Giese, A., Westaway, D., and Kretzschmar, $\mathrm{H}$. (1997). The cellular prion protein binds copper in vivo. Nature. 390, 684-687.

Brown, D.R., Hafiz, F., Glasssmith, L.L., Wong, B.S., Jones, I.M., Clive, C., and Haswell, S.J. (2000). Consequences of manganese replacement of copper for prion protein function and proteinase resistance, EMBO J. 19, 1180-1186.

Brown, D.R., Clive, C., and Haswell, S.J. (2001). Antioxidant activity related to copper binding of native prion protein. J. Neurochem. 76, 69-76.

Brown, D.R., Schmidt, B., and Kretzschmar, H.A. (1998). Effects of copper on survival of prion protein knockout neurons and glia. J. Neurochem. 70, 1686-1693.

Brown, L.R., and Harris, D.A. (2003). Copper and zinc cause delivery of the prion protein from the plasma membrane to a subset of early endosomes and the Golgi. J. Neurochem. 87, 353-363.

Burns, C.S., Aronoff-Spencer, E., Legname, G., Prusiner, S.B., Antholine, W.E., Gerfen, G.J., Peisach, J., and Millhauser, G.L. (2003). Copper coordination in the full-length, recombinant prion protein. Biochem. 42, 6794-803. 
Büeler, H., Fischer, M., Lang, Y., Bluethmann, H., Lipp, H.P., DeArmond, S.J., Prusiner, S.B., Aguet, M., and Weissmann, C. (1992). Normal development and behaviour of mice lacking the neuronal cell-surface PrP protein. Nature. 356, 577-582.

Caughey, B., and Baron, G.S. (2006). Prions and their partners in crime. Nature 443, 803-810.

Chesebro, B., Trifilo, M., Race, R., Meade-White, K., Teng, C., LaCasse, R., Raymond, L., Favara, C., Baron, G., Priola, S., Caughey, B., Masliah, E., and Oldstone, M. (2005)Anchorless prion protein results in infectious amyloid disease without clinical scrapie. Science 308, 1435-1439.

Deleault, N.R., Harris, B.T., Rees, J.R., and Supattapone, S. (2007). Formation of native prions from minimal components in vitro. Proc. Natl. Acad. Sci. USA 104, 9741-9746.

Fernaeus, S., and Land, T. (2005). Increased ironinduced oxidative stress and toxicity in scrapie-infected neuroblastoma cells. Neurosci. Lett. 382, 133-136.

Fernaeus, S., Halldin, J., Bedecs, K., and Land, T. (2005). Changed iron regulation in scrapie-infected neuroblastoma cells. Brain Res. Mol. Brain Res. 133, 266-273.

Gaasch, J.A., Lockman, P.R., Geldenhuys, W.J., Allen, D.D., and Van der Schyf, C.J. (2007). Brain iron toxicity: differential responses of astrocytes, neurons, and endothelial cells. Neurochem Res. 32, 1196-1208.

Gerlach, M., Ben-Shachar, D., Riederer, P., and Youdim, M.B. (1994). Altered brain metabolism of iron as a cause of neurodegenerative diseases J Neurochem. 63, 793-807.

Giese, A., Buchholz, M., Herms, J., and Kretzschmar, H.A. (2005). Mouse brain synaptosomes accumulate copper-67 efficiently by two distinct processes independent of cellular prion protein. J. Mol. Neurosci. 27, 347-54.

Giese, A., Levin, J., Bertsch, U., and Kretzschmar, H.A. (2004). Effect of metal ions on de novo aggregation of fulllength prion protein. Biochem. Biophys. Res. Commun. 320, 1240-1246.

Golts, N., Snyder, H., Frasier, M., Theisler, C., Choi, P., and Wolozin, B. (2002). Magnesium Inhibits Spontaneous and Iron-induced Aggregation of $\alpha$-Synuclein. J. Biol. Chem. 277, 16116-16123.

Gu, Y., Verghese, S., Mishra, R.S., Xu, X., Shi, Y., and Singh, N. (2003). Mutant prion protein-mediated aggregation of normal prion protein in the endoplasmic reticulum: implications for prion propagation and neurotoxicity. J. Neurochem. 84, 10-22.

Harris, D.A., and True, H.L. (2006). New insights into prion structure and toxicity. Neuron. 50, 353-357.

Hayashi,T., Shoji, M., and Abe, K. (2006). Molecular mechanisms of ischemic neuronal cell death--with relevance to Alzheimer's disease. Curr Alzheimer Res. 3, 351-358.

Hegde, R.S., Mastrianni, J.A., Scott, M.R., DeFea, K.A., Tremblay, P., Torchia, M., DeArmond, S.J., Prusiner, S.B., and Lingappa, V.R. (1998). A transmembrane form of the prion protein in neurodegenerative disease. Science. 279, 827-834.

Hegde, R.S., Tremblay, P., Groth, D., DeArmond, S.J., Prusiner, S.B., and Lingappa, V.R. (1999). Transmissible and genetic prion diseases share a common pathway of neurodegeneration. Nature. 402, 822-826.
Heller, U., Winklhofer, K.F., Heske, J., Reintjes, A., and Tatzelt, J. (2003). Post-translational import of the prion protein into the endoplasmic reticulum interferes with cell viability: a critical role for the putative transmembrane domain. J. Biol. Chem. 278, 36139-36147.

Herms, J., Tings, T., Gall, S., Madlung, A., Giese, A., Siebert, H., Schürmann, P., Windl, O., Brose, N., and Kretzschmar, $\mathrm{H}$. (1999). Evidence of presynaptic location and function of the prion protein. J. Neurosci. 19, 8866-8875.

Hesketh, S., Sassoon, J., Knight, R., and Brown, D.R. (2008). Elevated manganese levels in blood and CNS in human prion disease. Mol. Cell Neurosci. 37, 590-598.

Hesketh, S., Sassoon, J., Knight, R., Hopkins, J., and Brown, D.R. (2007). Elevated manganese levels in blood and central nervous system occur before onset of clinical signs in scrapie and bovine spongiform encephalopathy. J. Anim. Sci. 85, 1596-1609.

Hijazi, N., Shaked, Y., Rosenmann, H., Ben-Hur, T., and Gabizon, R. (2003). Copper binding to $\mathrm{PrP}^{\mathrm{C}}$ may inhibit prion disease propagation. Brain Res. 12, 192-200.

Hornshaw, M.P., McDermott, J.R., and Candy, J.M. (1995a). Copper binding to the $\mathrm{N}$-terminal tandem repeat regions of mammalian and avian prion protein. Biochem. Biophys. Res. Commun. 207, 621-629.

Hornshaw, M.P., McDermott, J.R., Candy, J.M., and Lakey, J.H. (1995b). Copper binding to the N-terminal tandem repeat region of mammalian and avian prion protein: structural studies using synthetic peptides, Biochem. Biophys. Res. Commun. 214, 993-999.

Jackson, G.S., Murray, I., Hosszu, L.L., Gibbs, N., Waltho, J.P., Clarke, A.R., and Collinge, J. (2001). Location and properties of metal-binding sites on the human prion protein, Proc. Natl. Acad. Sci. U. S. A. 98, 8531-8535.

Jeffrey, M., Goodsir, C.M., Race, R.E., and Chesebro, B. (2004). Scrapie-specific neuronal lesions are independent of neuronal PrP expression. Ann. Neurol. 55, 781-792.

Jeong, S.Y., and David, S. (2003). Glycosylphosphatidylinositol-anchored ceruloplasmin is required for iron efflux from cells in the central nervous system. J. Biol. Chem. 278, 27144-27148.

Jin, T., Gu, Y., Zanusso, G., Sy, M., Kumar, A., Cohen, M., Gambetti, P., and Singh, N. (2000). The chaperone protein $\mathrm{BiP}$ binds to a mutant prion protein and mediates its degradation by the proteasome. J. Biol. Chem. 275, 38699-38704.

Jobling, M.F., Huang, X., Stewart, L.R., Barnham, K.J., Curtain, C., Volitakis, I., Perugini, M., White, A.R., Cherny, R.A., Masters, C.L., Barrow, C.J., Collins, S.J., Bush, A.I., and Cappai, R. (2001). Copper and zinc binding modulates the aggregation and neurotoxic properties of the prion peptide PrP106-126. Biochem. 40, 8073-84.

Jobling, M.F., Stewart, L.R., White, A.R., McLean, C., Friedhuber, A., Maher, F., Beyreuther, K., Masters, C.L., Barrow, C.J., Collins, S.J., and Cappai, R. (1999). The hydrophobic core sequence modulates the neurotoxic and secondary structure properties of the prion peptide 106-126. J. Neurochem. 73, 1557-1565.

Jones, C.E., Abdelraheim, S.R., Brown, D.R., and Viles, J.H. (2004). Preferential $\mathrm{Cu}^{2+}$ coordination by His96 and His 111 induces beta-sheet formation in the unstructured amyloidogenic region of the prion protein. J. Biol. Chem. 279, 32018-32027. 
Jones, C.E., Klewpatinond, M., Abdelraheim, S.R., Brown, D.R., and Viles, J.H. (2005). Probing copper ${ }^{2+}$ binding to the prion protein using diamagnetic nickel ${ }^{2+}$ and $1 \mathrm{H}$ NMR: the unstructured $\mathrm{N}$ terminus facilitates the coordination of six copper ${ }^{2+}$ ions at physiological concentrations, J. Mol. Biol. 346, 1393-1407.

Kaplan, J. (2002). Mechanisms of cellular iron acquisition: another iron in the fire. Cell. 111, 603-606.

Kenward, A.G., Bartolotti, L.J., Burns, C.S. (2007). Copper and zinc promote interactions between membraneanchored peptides of the metal binding domain of the prion protein. Biochem. 46, 4261-4271.

Kiachopoulos, S., Heske, J., Tatzelt, J., and Winklhofer, K.F. (2004). Misfolding of the prion protein at the plasma membrane induces endocytosis, intracellular retention and degradation. Traffic. 5, 426-436.

Kim, B.H., Jun, Y.C., Jin, J.K., Kim, J.I., Kim, N.H., Leibold, E.A., Connor, J.R., Choi, E.K., Carp, R.I., and Kim, Y.S. (2007). Alteration of iron regulatory proteins (IRP1 and IRP2) and ferritin in the brains of scrapie-infected mice. Neurosci. Lett. 422, 158-163.

Kim, N.H., Choi, J.K., Jeong, B.H., Kim, J.I., Kwon, M.S., Carp, R.I., and Kim, Y.S. (2005). Effect of transition metals ( $\mathrm{Mn}, \mathrm{Cu}, \mathrm{Fe}$ ) and deoxycholic acid (DA) on the conversion of PrPC to PrPres. FASEB J. 19, 783-785.

Kim, N.H, Park, S.J., Jin, J.K., Kwon, M.S., Choi, E.K., Karp, R.I., and Kim, Y.S. (2000). Increased ferric iron content and iron-induced oxidative stress in the brains of scrapieinfected mice. Brain Res. 884, 98-103.

Kretzschmar, H.A., Tings, T., Madlung, A., Giese, A., Herms, J. (2000). Function of $\operatorname{PrP}(C)$ as a copper-binding protein at the synapse. Arch. Virol. Suppl. 16, 239-49.

Kristiansen, M., Messenger, M.J., Klohn, P.C., Brandner, S., Wadsworth, J.D., Collinge, J., and Tabrizi, S.J. (2005). Disease-related prion protein forms aggresomes in neuronal cells leading to caspase-activation and apoptosis. J. Biol. Chem. 280, 38851-38861.

Kuczius, T., Buschmann. A., Zhang, W., Karch, H., Becker, K., Peters, G., and Groschup, M.H. (2004). Cellular prion protein acquires resistance to proteolytic degradation following copper ion binding. Biol. Chem. 385, 739-747.

Lee, K.S., Raymond, L.D., Schoen, B., Raymond, G.J., Kett, L., Moore, R.A., Johnson, L.M., Taubner, L., Speare, J.O., Onwubiko, H.A., Baron, G.S., Caughey, W.S., and Caughey, B. (2007). Hemin interactions and alterations of the subcellular localization of prion protein. J. Biol. Chem. 282, 36525-36533.

Liu, M., Yu, S., Yang, J., Yin, X., and Zhao, D. (2007). RNA and $\mathrm{CuCl} 2$ induced conformational changes of the recombinant ovine prion protein. Mol. Cell Biochem. 294, 197-203.

Ma, J., and Lindquist, S. (2002). Conversion of PrP to a self-perpetuating $\mathrm{PrPSc}^{-l i k e}$ conformation in the cytosol. Science. 298, 1785-1788.

Ma, J., Wollmann, R., and Lindquist, S. (2002). Neurotoxicity and neurodegeneration when $\operatorname{PrP}$ accumulates in the cytosol. Science. 298, 1781-1785.

Mallucci, G., Dickinson, A., Linehan, J., Klohn, P.C., Brandner, S., and Collinge, J. (2003). Depleting neuronal $\mathrm{PrP}$ in prion infection prevents disease and reverses spongiosis. Science. 302, 871-874.

Mishra, R.S., Basu, S., Gu, Y., Luo, X., Zou, W.Q., Mishra, R., Li, R., Chen, S.G., Gambetti, P., Fujioka, H., and
Singh, N. (2004). Protease-resistant human prion protein and ferritin are cotransported across Caco-2 epithelial cells: implications for species barrier in prion uptake from the intestine. J. Neurosci. 24, 11280-11290.

Mishra, R.S., Gu, Y., Bose, S., Verghese, S., Kalepu, S., Singh, N. (2002). Cell surface accumulation of a truncated transmembrane prion protein in GerstmannStraussler-Scheinker disease P102L. J. Biol. Chem. 277, 24554-24561.

Miura, T., Sasaki, S., Toyama, A., and Takeuchi, H. (2005). Copper reduction by the octapeptide repeat region of prion protein: $\mathrm{pH}$ dependence and implications in cellular copper uptake. Biochem. 44, 8712-8720.

Moos, T., and Morgan, E.H. (2004). The metabolism of neuronal iron and its pathogenic role in neurological disease. Ann. N. Y. Acad. Sci. 1012, 14-26.

Orem, N.R., Geoghegan, J.C., Deleault, N.R., Kascsak, R., and Supattapone, S. (2006). Copper (II) ions potently inhibit purified PrPres amplification. J. Neurochem. 96, 1409-1415.

Ostrerova-Golts, N., Petrucelli, L., Hardy, J., Lee, J.M., Farer, M., and Wolozin, B. (2000). The A53T alphasynuclein mutation increases iron-dependent aggregation and toxicity. J. Neurosci. 20,6048-6054.

Paik, S.R., Shin, H.J., and Lee, J.H. (2000). Metal-catalyzed oxidation of alpha-synuclein in the presence of Copper (II) and hydrogen peroxide. Arch. Biochem. Biophys. 378, 269-277.

Pamplona, R., Naudí, A., Gavín, R., Pastrana, M.A., Sajnani, G., Ilieva, E.V., Del Río, J.A., Portero-Otín, M., Ferrer, I., and Requena, J.R. (2008). Increased oxidation, glycoxidation, and lipoxidation of brain proteins in prion disease. Free Radic Biol Med. 45, 1159-1166.

Pan, K.M., Stahl, N., and Prusiner, S.B. (1992). Purification and properties of the cellular prion protein from Syrian hamster brain, Protein Sci. 1, 1343-1352.

Pauly, P.C., and Harris, D.A. (1998). Copper stimulates endocytosis of the prion protein. J. Biol. Chem. 273, 33107-33110.

Perera, W.S.S., and Hooper, N.M. (2001). Ablation of the metal ion-induced endocytosis of the prion protein by disease-associated mutation of the octarepeat region. Curr Biol. 11, 519-523.

Petersen, R.B., Siedlak, S.L., Lee, H.G., Kim, Y.S., Nunomura, A., Tagliavini, F., Ghetti, B., Cras, P., Moreira, P.I., Castellani, R.J., Guentchev, M., Budka, H., Ironside, J.W., Gambetti, P., Smith, M.A., and Perry, G. (2005). Redox metals and oxidative abnormalities in human prion diseases. Acta Neuropathol. (Berl). 110, 232-238.

Prusiner, S.B. (1998). Prions. Proc. Natl. Acad. Sci. U. S. A. 95, 3363-3383.

Qin, K., Yang, Y., Mastrangelo, P., and Westaway, D. (2002) Mapping $\mathrm{Cu}(\mathrm{II})$ binding sites in prion proteins by diethyl pyrocarbonate modification and matrix-assisted laser desorption ionization-time of flight (MALDI-TOF) mass spectrometric footprinting. J. Biol. Chem. 277, 1981-1990.

Quaglio, E., Chiesa, R., and Harris, D.A. (2001). Copper converts the cellular prion protein into a protease-resistant species that is distinct from the scrapie isoform. J. Biol. Chem. 276, 11432-11438.

Rossi, L., Lombardo, M.F., Ciriolo, M.R., and Rotilio, G. (2004). Mitochondrial dysfunction in neurodegenerative 
diseases associated with copper imbalance. Neurochem Res. 29, 493-504.

Roucou, X., and LeBlanc, A.C. (2005). Cellular prion protein neuroprotective function: implications in prion diseases. J. Mol. Med. 83, 3-11.

Roucou, X., Gains, M., and LeBlanc, A.C. (2004). Neuroprotective functions of prion protein. J. Neurosci. Res. 75, 153-161.

Roucou, X., Giannopoulos, P.N., Zhang, Y., Jodoin, J., Goodyer, C.G., LeBlanc, A. (2005). Cellular prion protein inhibits proapoptotic Bax conformational change in human neurons and in breast carcinoma MCF-7 cells. Cell Death Differ. 12, 783-795.

Sigurdsson, E.M., Brown, D.R., Alim, M.A., Scholtzova, H., Carp, R., Meeker, H.C., Prelli, F., Frangione, B., and Wisniewski, T. (2003). Copper chelation delays the onset of prion disease. J. Biol. Chem. 278, 46199-46202.

Singh, A., Isaac, A.O., Luo, X., Mohan, M.L., Cohen, M.L., Chen, F., Kong, Q., Bartz, J., and Singh, N. (2009a). Abnormal brain iron homeostasis in human and animal prion disorders. Plos Pathog. 5, e1000336.

Singh, A., Mohan, M.L., Isaac, A.O., Luo, X., and Singh, N. (2009b). Prion protein modulates cellular iron metabolism: Implications for prion disease pathogenesis. PlosOne. 4, e4468.

Singh, A., Kong, Q., Luo, X., Petersen, R.B., Meyerson, H., and Singh N. (2009c). Prion protein knock-out mice are iron deficient: A functional role for PrP in iron metabolism. Plos One. 4, e6115.

Smith, M.A., Harris, P.L., Sayre, L.M., and Perry, G. (1997). Iron accumulation in Alzheimer disease is a source of redox-generated free radicals. Proc. Natl. Acad. Sci. U. S. A. 94, 9866-9868.

Smith, D.G., Cappai R., and Barnham K.J. (2007). The redox chemistry of the Alzheimer's disease amyloid beta peptide. Biochim Biophys Acta.1768,1976-1990.

Solforosi, L., Criado, J.R., McGavern, D.B., Wirz, S., Sánchez-Alavez, M., Sugama, S., DeGiorgio, L.A., Volpe, B.T., Wiseman, E., Abalos, G., Masliah, E., Gilden, D., Oldstone, M.B., Conti, B., and Williamson, R.A. (2004). Cross-linking cellular prion protein triggers neuronal apoptosis in vivo. Science. 303, 1514-1516.

Stuermer, C.A., and Plattner, H. (2005). The 'lipid raft' microdomain proteins reggie-1 and reggie-2 (flotillins) are scaffolds for protein interaction and signalling. Biochem. Soc. Symp. 72, 109-118.

Takahashi, M., Ko, L.W., Kulathingal, J., Jiang, P., Sevlever, D., and Yen, S.H. (2007). Oxidative stress-induced phosphorylation, degradation and aggregation of alphasynuclein are linked to upregulated CK2 and cathepsin D. Eur. J. Neurosci. 26, 863-874.

Thackray, A.M., Knight, R., Haswell, S.J., Bujdoso, R., and Brown, D.R. (2002). Metal imbalance and compromised antioxidant function are early changes in prion disease. Biochem. J. 362, 253-258.

Thompson, K.J., Shoham, S., and Connor, J.R. (2001). Iron and neurodegenerative disorders. Brain Res. Bull. 55, 155-164.
Treiber, C., Simons, A., and Multhaup, G. (2006). Effect of copper and manganese on the de novo generation of protease-resistant prion protein in yeast cells. Biochem. 45, 6674-6680.

Treiber, C., Thompsett, A.R., Pipkorn, R., Brown, D.R., Multhaup, G. (2007). Real-time kinetics of discontinuous and highly conformational metal-ion binding sites of prion protein. J. Biol. Inorg. Chem. 12, 711-720.

Tsenkova, R.N., Iordanova, I.K., Toyoda, K., and Brown, D.R. (2004). Prion protein fate governed by metal binding. Biochem. Biophys. Res. Commun. 325, 1005-1012.

Vassallo, N., and Herms, J. (2003). Cellular prion protein function in copper homeostasis and redox signalling at the synapse. J. Neurochem. 86, 538-544.

Waggoner, D.J., Drisaldi, B., Bartnikas, T.B., Casareno, R.L., Prohaska, J.R., Gitlin, J.D., and Harris, D.A. (2000). Brain copper content and cuproenzyme activity do not vary with prion protein expression level. J. Biol. Chem. 275, 7455-7458.

Waheed, A., Grubb, J.H., Zhou, X.Y., Tomatsu, S., Fleming, R.E., Costaldi, M.E., Britton, R.S., Bacon. B.R., and Sly, W.S. (2002). Regulation of transferrin-mediated iron uptake by HFE, the protein defective in hereditary hemochromatosis. Proc. Natl. Acad. Sci. U. S. A. 99, 3117-3122.

Walter, E.D, Stevens, D.J., Visconte, M.P., and Millhauser, G.L. (2007). The prion protein is a combined zinc and copper binding protein: $\mathrm{Zn}^{2+}$ alters the distribution of $\mathrm{Cu}^{2+}$ coordination modes. J. Am. Chem. Soc. 129, 15440-15441.

Wang, X, Wang, F., Arterburn, L., Wollmann, R., and Ma, J. (2006). The interaction between cytoplasmic prion protein and the hydrophobic lipid core of membrane correlates with neurotoxicity. J. Biol. Chem. 281, 13559-13565.

Watt, N.T, and Hooper, N.M. (2003). The prion protein and neuronal zinc homeostasis. Trends Biochem. Sci. 28, 406-410.

Wong, B.S., Brown, D.R., Pan, T., Whiteman, M., Liu, T., Gambetti, P., Olesik, J., Rubenstein, R., and Sy, M.S. (2001a). Oxidative impairment in scrapie-infected mice is associated with brain metals. perturbations and altered antioxidant activities. J. Neurochem. 79, 689-698.

Wong, B.S., Chen, S.G., Colucci, M., Xie, Z., Pan, T., Liu, T., Li, R., Gambetti, P., Sy, M.S., and Brown, D.R. (2001b). Aberrant metal binding by prion protein in human prion disease. J. Neurochem. 78, 1400-1408.

Wong, B.S., Liu, T., Li, R., Pan, T., Petersen, R.B., Smith, M.A., Gambetti, P., Perry, G., Manson, J.C., Brown, D.R., and Sy, M-S. (2001c). Increased levels of oxidative stress markers detected in the brains of mice devoid of prion protein, J. Neurochem. 76, 565-572.

Yadavalli, R., Guttmann, R.P., Seward, T., Centers, A.P., Williamson, R.A., and Telling, G.C. (2004). Calpain-dependent endoproteolytic cleavage of PrPSc modulates scrapie prion propagation. J. Biol. Chem. 279, 21948-21956. 


\section{Further Reading}

Caister Academic Press is a leading academic publisher of advanced texts in microbiology, molecular biology and medical research. Full details of all our publications at caister.com

- MALDI-TOF Mass Spectrometry in Microbiology Edited by: M Kostrzewa, S Schubert (2016) www.caister.com/malditof

- Aspergillus and Penicillium in the Post-genomic Era Edited by: RP Vries, IB Gelber, MR Andersen (2016) www.caister.com/aspergillus2

- The Bacteriocins: Current Knowledge and Future Prospects Edited by: RL Dorit, SM Roy, MA Riley (2016)

www.caister.com/bacteriocins

- Omics in Plant Disease Resistance Edited by: V Bhadauria (2016) www.caister.com/opd

- Acidophiles: Life in Extremely Acidic Environments Edited by: R Quatrini, DB Johnson (2016) www.caister.com/acidophiles

- Climate Change and Microbial Ecology: Current Research and Future Trend

Edited by: J Marxsen (2016)

www.caister.com/climate

- Biofilms in Bioremediation: Current Research and Emerging Technologies

Edited by: G Lear (2016)

www.caister.com/biorem

- Microalgae: Current Research and Applications Edited by: MN Tsaloglou (2016) www.caister.com/microalgae

- Gas Plasma Sterilization in Microbiology: Theory, Applications, Pitfalls and New Perspectives Edited by: H Shintani, A Sakudo (2016) www.caister.com/gasplasma

- Virus Evolution: Current Research and Future Directions Edited by: SC Weaver, M Denison, M Roossinck, et al. (2016) www.caister.com/virusevol

- Arboviruses: Molecular Biology, Evolution and Control Edited by: N Vasilakis, DJ Gubler (2016) www.caister.com/arbo

- Shigella: Molecular and Cellular Biology Edited by: WD Picking, WL Picking (2016) www.caister.com/shigella

-Aquatic Biofilms: Ecology, Water Quality and Wastewater Treatment

Edited by: AM Romaní, H Guasch, MD Balaguer (2016)

www.caister.com/aquaticbiofilms

- Alphaviruses: Current Biology

Edited by: S Mahalingam, L Herrero, B Herring (2016)

www.caister.com/alpha

- Thermophilic Microorganisms

Edited by: F Li (2015)

www.caister.com/thermophile
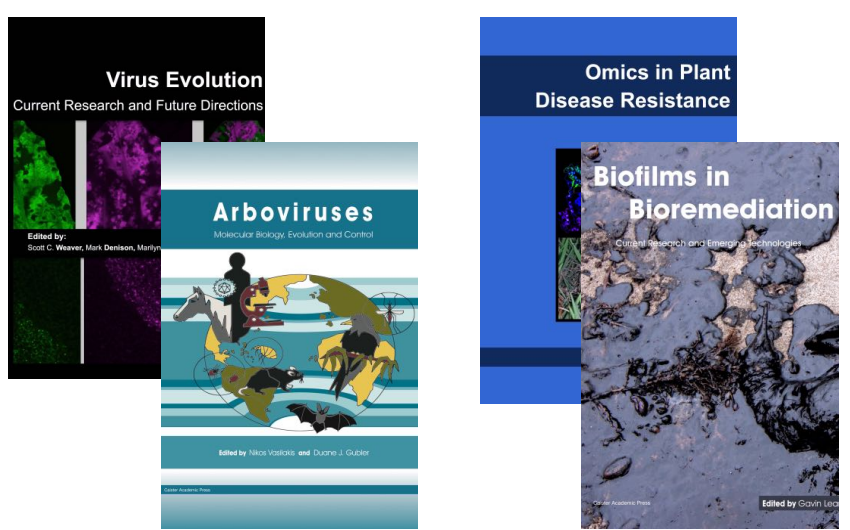
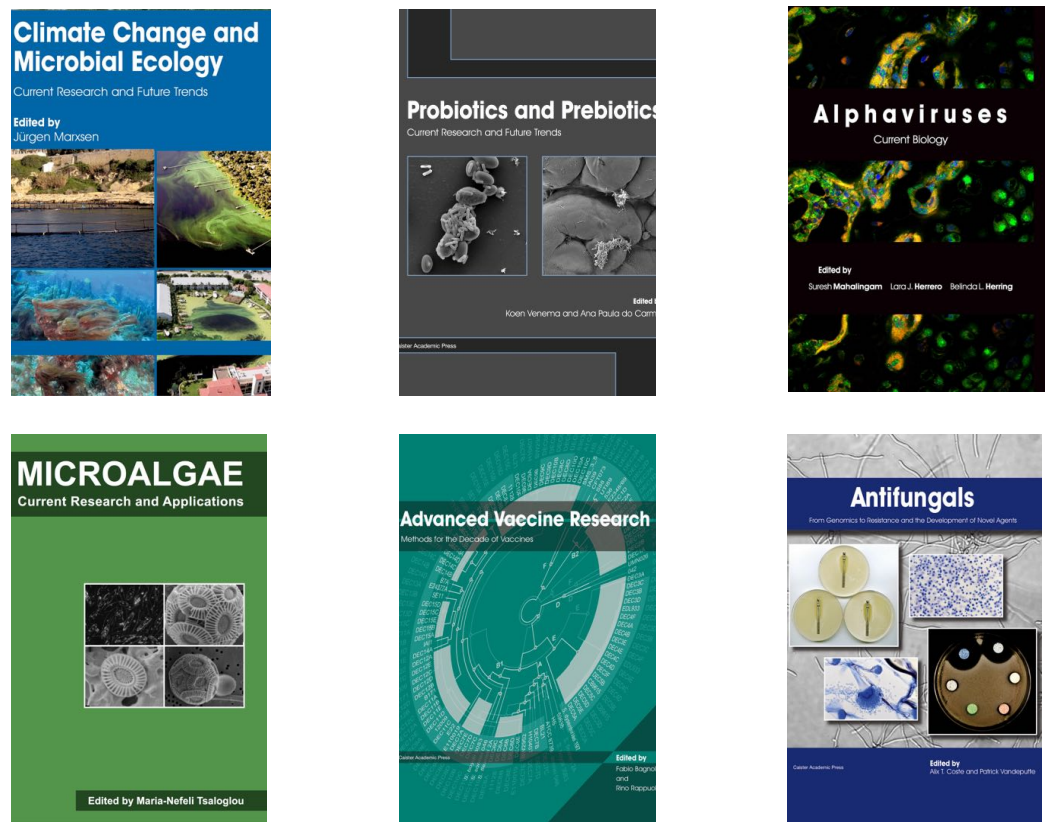

- Flow Cytometry in Microbiology: Technology and Applications Edited by: MG Wilkinson (2015) www.caister.com/flow

- Probiotics and Prebiotics: Current Research and Future Trends Edited by: K Venema, AP Carmo (2015) www.caister.com/probiotics

- Epigenetics: Current Research and Emerging Trends Edited by: BP Chadwick (2015) www.caister.com/epigenetics2015

- Corynebacterium glutamicum: From Systems Biology to Biotechnological Applications

Edited by: A Burkovski (2015)

www.caister.com/cory2

- Advanced Vaccine Research Methods for the Decade of Vaccines

Edited by: F Bagnoli, R Rappuoli (2015)

www.caister.com/vaccines

- Antifungals: From Genomics to Resistance and the Development of Novel Agents

Edited by: AT Coste, P Vandeputte (2015)

www.caister.com/antifungals

- Bacteria-Plant Interactions: Advanced Research and Future Trends Edited by: J Murillo, BA Vinatzer, RW Jackson, et al. (2015) www.caister.com/bacteria-plant

\section{- Aeromonas}

Edited by: J Graf (2015)

www.caister.com/aeromonas

- Antibiotics: Current Innovations and Future Trends

Edited by: S Sánchez, AL Demain (2015)

www.caister.com/antibiotics

- Leishmania: Current Biology and Contro Edited by: S Adak, R Datta (2015) www.caister.com/leish2

- Acanthamoeba: Biology and Pathogenesis (2nd edition) Author: NA Khan (2015)

www.caister.com/acanthamoeba2

- Microarrays: Current Technology, Innovations and Applications Edited by: Z He (2014)

www.caister.com/microarrays2

- Metagenomics of the Microbial Nitrogen Cycle: Theory, Methods and Applications

Edited by: D Marco (2014)

www.caister.com/n2 